\title{
Physico-chemical Characterization of Gosainkunda Lake
}

\author{
Rosha Raut $^{1}$, Subodh Sharma ${ }^{1}$ Roshan M. Bajracharya ${ }^{1}$, \\ Chhatra Mani Sharma² and Smriti Gurung ${ }^{1}$ \\ ${ }^{1}$ Aquatic Ecology Centre, School of Science \\ Kathmandu University, Dhulikhel, Kavre \\ ${ }^{2}$ Human and Natural Resources Studies Centre, School of Arts \\ Kathmandu University, Kathmandu \\ e-mail: rosha@ku.student.edu.np
}

\begin{abstract}
High altitude lakes are very sensitive to climate change due to their small catchment area, limited vegetation cover, surface water with low nutrients, and thin soil and low bedrock weathering rates. The present study was focused on high altitude Himalayan Lake Gosainkunda, situated at an elevation of $4300 \mathrm{~m}$ in the Langtang National Park, and carried out during the post- monsoon season (October) in 2010. The main aim of the study was to assess the water quality quantitatively considering the anthropogenic as well as natural impacts in the lake. The water samples were collected at six different sites to represent entirely the quality of the lake. The sampling sites were systematically designated as the inlet, outlet, human influence site, littoral zone, middle (central) and the deepest part of the lake. Some major cations $\left(\mathrm{Ca}^{++}, \mathrm{Mg}^{++}, \mathrm{Na}^{+} \& \mathrm{~K}^{+}\right)$and anions $\left(\mathrm{Cl}^{-}, \mathrm{SO}_{4}^{-} \& \mathrm{HCO}_{3}^{-}\right)$were analyzed; the cation type is dominated by $\mathrm{Ca}^{++}(64 \%)$ while the anions are dominated by $\mathrm{Cl}^{-}$(49\%). Among the trace elements ( $\mathrm{Al}, \mathrm{Fe}, \mathrm{Mn}, \mathrm{Zn}$, $\mathrm{Cu}, \mathrm{Cd}, \mathrm{Cr}, \mathrm{Ni}, \mathrm{Pb} \& \mathrm{As})$, except for $\mathrm{Al}$ and $\mathrm{Fe}$, all others were found below the detection limit.
\end{abstract}

Key words: Physical and chemical parameters, high altitude lakes, water quality

\section{Introduction}

High Elevation catchments are characterized by dilute surface waters, small terrestrial area, limited vegetative cover, thin soils and also bedrock weathering rate is very low (Psenner 1989, Drever \& Zobrist 1992; Strang et al. 2010). The high altitude lakes are pristine habitats, undisturbed by direct anthropogenic activities due to their remoteness in location (Koinig et al. 1998). They are mostly oligotrophic as compared to lowland lakes. The lakes in these remote areas are particularly suitable for study, where the climate signals are maximized mainly due to the limited importance of human impact (Smol et al. 1991). Although, high altitude lakes in Nepalese Himalaya were considered as pristine (Aizaki et al. 1987), they are being affected by various environmental factors and climatic change due to acidification, eutrophication, global warming and UV radiation (Cantonati et al. 2001). Mountain lakes located at the high elevation are more susceptible to atmospheric inputs than lowland lakes due to factors such as climate, shallow soils, small watersheds and rapid flushing rates (Mosello et al. 1995,
Galassi et al. 1997, Lami et al. 1998).

In the context of Nepal, there are 79 large standing freshwater bodies in the mountain regions of Nepal (Gujja et al. 2007). Nepal has a total of 5358 lakes, of which, 2227 (42\%) are situated above $3000 \mathrm{~m}$ elevation (Bhuju et al. 2010). Numerous limnological studies had been carried out in lowland and middle mountains compared to high altitude although Nepal has a large number of high altitude freshwater bodies. The first high altitude limnological study in Nepal was carried out by Löffler (1969), who provided the data on morphometry, temperature, chemistry and biology of 24 lakes at altitudes between 4500 and $5600 \mathrm{~m}$ in the Mount Everest region (Khumbu Valley). Although there have been several studies on high mountain lakes, very few studies focused on water chemistry (Loffler 1969, Aizaki et al. 1987, Tartari et al. 1998 a \& b, Lacoul \& Freedman 2005). Studies in other lakes include Okino and Satosh 1986, Aizaki et al. 1987, Liu \& Sharma 1988, Tartari et al. 1998 a). Limnological studies in Sagarmatha National Park have been carried out in late 1990s. These studies are based on water 
chemistry (Gosso et al. 1993, Tartari et al. 1997), and Lake Biota (Manca et al. 1994, Manca \& Mura 1997). After several years Lacoul and Freedman (2005) made the contribution, especially in the physical and chemical limnology of lentic water bodies of Nepal in different altitudinal gradient ranging from tropical to lowland (77 m) and high altitude alpine region (up to $4980 \mathrm{~m}$ ).

In fact, there is still a lack of information on high altitude lakes although much research has been done in diverse fields. This is likely due to poor accessibility and harsh working conditions.

\section{Methodology}

Study area

Gosainkunda, the study area is a famous high Himalayan (alpine zone) lake situated above the tree line in the

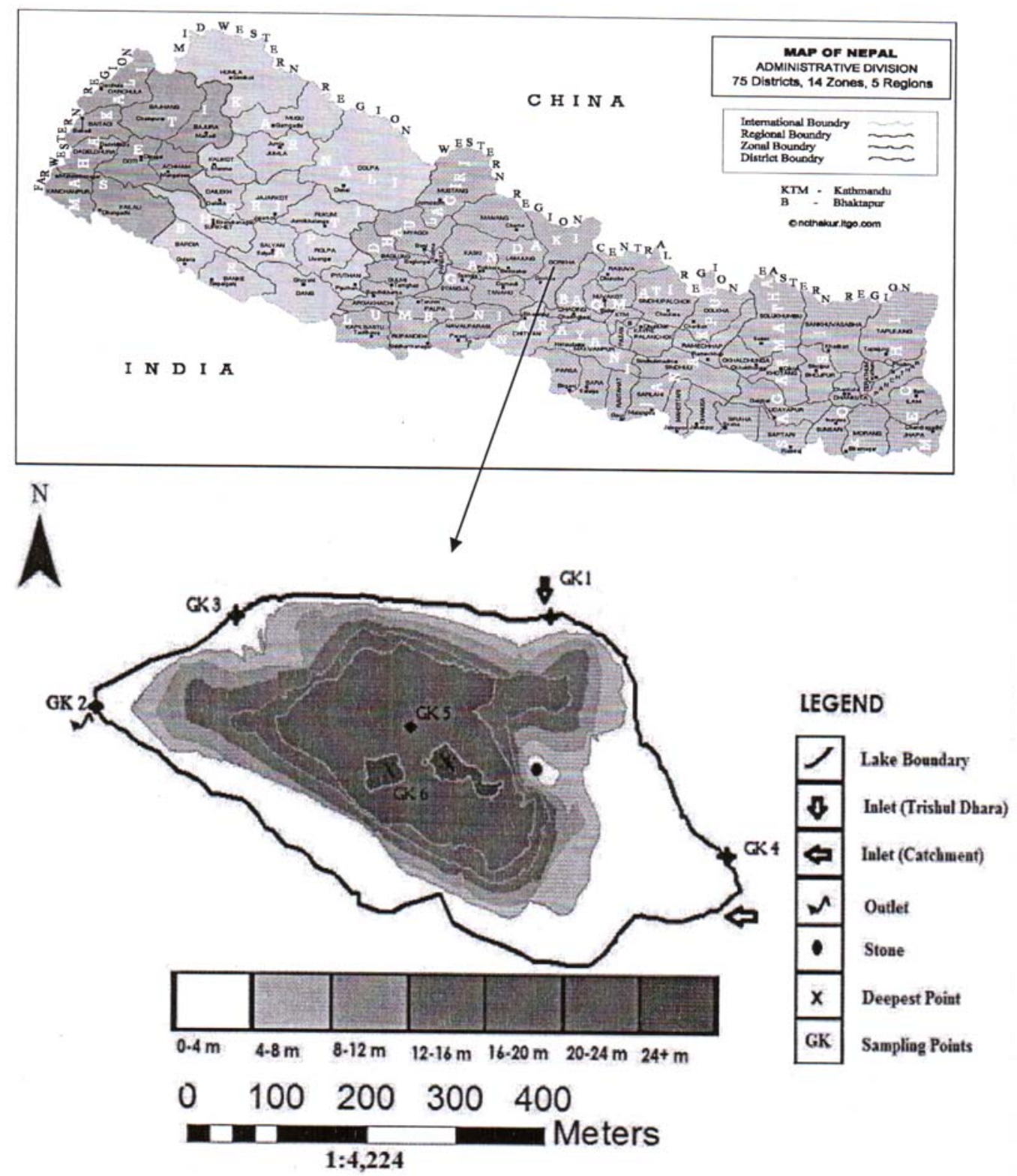

Fig.1. Map of Nepal indicating study location and lake Bathymetry showing sampling sites. Source: (Niraula, 2011). Location description of sampling sites GK1 to GK6 is presented in Table 2. 
Langtang National Park in Rasuwa district of Nepal. It has high socio-cultural and religious importance. Every year, during the event of Janaipurnima (full moon festival in August) hundreds of Hindu and Buddhist pilgrims visit this lake. As a high altitude lake it has national and international importance for the people all over the world. Gosainkunda and associated lakes have been included as in the list of world Ramsar site no. 1693 on September 23, 2007 (Kafle \& Savillo 2009). The lake remains frozen for six months in winter (October to June). It is formed by glacial or snow melt water in the eastern and central Himalayas (Lacoul \& Fredman 2005). Some topographical characteristics of lake are given in Table 2.
Table1. Topographical characteristics of lake Gosainkund (Source: (Niraula 2009)

\begin{tabular}{ll}
\hline Altitude (m asl) & 4300 \\
Longitude (East) & $28^{0} 05.00^{\prime}$ \\
Latitude (North) & $85^{0} 24.96^{\prime}$ \\
Lake surface area (ha) & 13.8 \\
Volume (m ${ }^{3}$ ) & 1464084.604 \\
Maximum depth (m) & 24.1 \\
\hline
\end{tabular}

The lake can be reached in two days trekking from Dhunche, Rashuwa district through an adventurous 118 $\mathrm{km}$ mountain road from Kathmandu. In the surrounding area of Gosainkunda, there are 108 lakes of small to medium size. Mainly visible lakes in routes are commonly Sharaswatikund, Bhairabkunda and Gosainkunda.

Table 2. Sampling sites (locations) with longitude and latitude

\begin{tabular}{llll}
\hline Site Code & Longitude (East) & Latitude (North) & Sampling locations \\
\hline GK1 & $85^{0} 24.811^{\prime \prime}$ & $28^{0} 04.992^{\prime \prime}$ & Inlet (Trishul Dhara) \\
GK2 & $85^{0} 24.626^{\prime \prime}$ & $28^{0} 05.041^{\prime \prime}$ & Outlet \\
GK3 & $85^{0} 24.710^{\prime \prime}$ & $28^{0} 05.041^{\prime \prime}$ & Human influence area \\
GK4 & $85^{0} 24.001^{\prime \prime}$ & $28^{0} 04.912^{\prime \prime}$ & Littoral zone \\
GK5 & $85^{0} 24.811^{\prime \prime}$ & $28^{0} 05.041^{\prime \prime}$ & Middle (centre) of the lake \\
GK6 & $85^{0} 24.802^{\prime \prime}$ & $28^{0} 04.982^{\prime \prime}$ & Deepest point of the lake \\
\hline
\end{tabular}

\section{Field Sampling and laboratory analysis}

The sampling of lake was started on a sunny day from noon and completed in the evening day of $25^{\text {th }}$ October, 2010. Although middle surface water samples can be considered as the representative of the lakes (Göransson et al. 2003), the water samples were collected at six different sites of the lake to represent the water quality of the entire lake. The sampling sites were inlet, outlet, human influence sites, littoral zone, middle (central) and the deepest point of the lake, and coded as GK1, GK2, GK3, GK4, GK5 and GK6 respectively.

Physico - chemical parameters like $\mathrm{pH}$, temperature, conductivity, and dissolved oxygen were measured by using multiparameter probe (Orion Star Series Multimeter set) in situ. Alkalinity was analyzed immediately after the collection of samples by trimetric method. For analysis of other chemical parameters, such as nitrate, nitrite, ammonia, total nitrogen and phosphate, the samples were collected in a prewashed $500 \mathrm{ml}$ clean plastic container and preserved with conc. $\mathrm{H}_{2} \mathrm{SO}_{4}$ and also followed by same volume of samples in unpreserved condition for other chemical parameters like sodium, potassium, total silica, etc. However, for the trace metals like Fe, Mn, $\mathrm{Cu}, \mathrm{Zn}, \mathrm{Cd}, \mathrm{Cr}, \mathrm{Ni}, \mathrm{Pb}$ and $\mathrm{As}$, the samples were collected in pre acid washed plastic container and preserved with conc. $\mathrm{HNO}_{3}$ and brought to the laboratory at Aquatic Ecology Center/Kathmandu University for further analyses. Fresh standard solutions were prepared from stock during analysis of each and every parameter and kept at least 4 different concentrations for calibration. All the sample collection techniques, quality control technique and analytical methods were followed by using Standard Methods for the Examination of Water and Wastewater (APHA, AWWA \& WEF, 1998). The analyzed physico-chemical parameters and their brief test methods are mentioned in Table 3. 
Nepal Journal of Science and Technology Vol. 13, No. 1 (2012) 107-114

Table 3. List of analyzed physico- chemical parameters in water samples of Gosainkunda lake

\begin{tabular}{|c|c|c|}
\hline Parameters & Units & Test methods \\
\hline Water temperature & ${ }^{\circ} \mathrm{C}$ & Thermometer \\
\hline $\mathrm{pH}$ & - & Multi Parameter Probe \\
\hline Electrical conductivity & $\mu \mathrm{S} / \mathrm{cm}$ & Multi Parameter Probe \\
\hline Turbidity & NTU & Nephalometric (Turbidity meter) \\
\hline Total dissolved solids (TDS) & $\mathrm{mgL}^{-1}$ & Gravimetric \\
\hline Total suspended solids (TSS) & $\mathrm{mgL}^{-1}$ & Gravimetric \\
\hline Bicarbonate alkalinity $\left(\mathrm{HCO}_{3}^{-}\right)$ & $\mathrm{mgL}^{-1}$ & Titrimetric $\left(\mathrm{H}_{2} \mathrm{SO}_{4}\right)$ \\
\hline Chloride $\left(\mathrm{Cl}^{-}\right)$ & $\mathrm{mgL}^{-1}$ & Argentrometric \\
\hline Total hardness as $\mathrm{CaCO}_{3}$ & $\mathrm{mgL}^{-1}$ & EDTA Titration \\
\hline Calcium $\left(\mathrm{Ca}^{++}\right)$ & $\mathrm{mgL}^{-1}$ & EDTA Titration \\
\hline Magnesium $\left(\mathrm{Mg}^{++}\right)$ & $\mathrm{mgL}^{-1}$ & EDTA Titration \\
\hline Dissolved oxygen (DO) & $\mathrm{mgL}^{-1}$ & Multi Parameter Probe \\
\hline Sodium $\left(\mathrm{Na}^{+}\right)$ & $\mathrm{mgL}^{-1}$ & Atomic Absorption Spectrometer (AAS) \\
\hline Potassium $\left(\mathrm{K}^{+}\right)$ & $\mathrm{mgL}^{-1}$ & Atomic Absorption Spectrometer (AAS) \\
\hline Sulphate $\left(\mathrm{SO}_{4}^{-}\right)$ & $\mathrm{mgL}^{-1}$ & Spectrophotometric \\
\hline Total silica & $\mathrm{mgL}^{-1}$ & Molibdosilicate \\
\hline Orthophosphorus & $\mathrm{mgL}^{-1}$ & Ammonium molybdate ascorbic acid red. ${ }^{n}$ \\
\hline Total phosphate (TP) & $\mathrm{mgL}^{-1}$ & $\begin{array}{l}\text { Potassium persulphate digt }{ }^{\mathrm{n}} \text { followed by Ammonium molybdate } \\
\text { ascorbic acid reduction. }\end{array}$ \\
\hline Organic nitrogen $(\mathrm{ON})$ & $\mathrm{mgL}^{-1}$ & Kjeldhal digestion \\
\hline Total nitrogen $(\mathrm{TN})$ & $\mathrm{mgL}^{-1}$ & $\mathrm{~N}-\mathrm{NO}_{3}+\mathrm{N}-\mathrm{NO}_{2}+\mathrm{N}-\mathrm{NH}_{3}+$ Organic nitrogen \\
\hline Aluminum (Al) & $\mathrm{mgL}^{-1}$ & Spectrophotometric (Erichrome Cyanine) \\
\hline \multicolumn{3}{|l|}{ Iron, Manganese, Zinc, Copper , } \\
\hline Cadmium, Chromium, Nickel \& Lead & $\mathrm{mgL}^{-1}$ & Atomic Absorption Spectrometer (AAS) \\
\hline Arsenic (As) & $\mathrm{mgL}^{-1}$ & Atomic Absorption Spectrometer (AAS) (Hydride Generation - vapour) \\
\hline
\end{tabular}

\section{Data analysis}

Descriptive statistics was performed using EXCEL worksheet, Pearson correlation between variables was estimated using the statistic software SPSS version 10 .

\section{Results and Discussion}

The average value of $\mathrm{pH}$ was observed to be 7 indicating that the lake water is neutral. A low $\mathrm{pH}$ value was observed at the deepest point while highest was noted for the outlet of the lake, i.e. 5.7 and 8.9 respectively. The data on $\mathrm{pH}$ of water are given in table 4. 
R. Raut et al./Physico-chemical Characterization.......

Table 4. Mean, maximum, minimum and standard deviation values of analyzed parameters

\begin{tabular}{|c|c|c|c|c|}
\hline Parameters & Units & Mean (stsd) & Min. Value & Max. value \\
\hline Temperature & ${ }^{0} \mathrm{C}$ & $6.65( \pm 1.790)$ & 2.7 & 7.9 \\
\hline $\mathrm{pH}$ & - & $7.00( \pm 1.075)$ & 5.70 & 8.90 \\
\hline Electrical Conductivity & $\mu \mathrm{S} / \mathrm{cm}$ & $11.66( \pm 5.249)$ & 8.00 & 22.0 \\
\hline Turbidity & NTU & $3.87( \pm 2.927)$ & $<1$ & 8.00 \\
\hline Total Dissolved Solids (TDS) & $\mathrm{mgL}^{-1}$ & $7.17( \pm 4.981)$ & 2.00 & 14.0 \\
\hline Total Suspended Solids (TSS) & $\mathrm{mgL}^{-1}$ & $3.50( \pm 3.403)$ & 1.00 & 11.0 \\
\hline Bicarbonate Alkalinity $\left(\mathrm{HCO}_{3}^{-}\right)$ & $\mathrm{mgL}^{-1}$ & $17.49( \pm 3.284)$ & 12.2 & 19.52 \\
\hline Chloride (Cl-) & $\mathrm{mgL}^{-1}$ & $20.50( \pm 13.781)$ & 9.00 & 49.0 \\
\hline Total Hardness as $\mathrm{CaCO}_{3}$ & $\mathrm{mgL}^{-1}$ & $14.0( \pm 6.904)$ & 9.00 & 29.0 \\
\hline Calcium $\left(\mathrm{Ca}^{++}\right)$ & $\mathrm{mgL}^{-1}$ & $3.47( \pm 2.055$ & 2.40 & 8.02 \\
\hline Magnesium $\left(\mathrm{Mg}^{++}\right)$ & $\mathrm{mgL}^{-1}$ & $1.30( \pm 0.654)$ & 0.24 & 2.19 \\
\hline Dissolved Oxygen (DO) & $\mathrm{mgL}^{-1}$ & $8.55( \pm 5.435)$ & 3.60 & 17.5 \\
\hline Sodium $\left(\mathrm{Na}^{+}\right)$ & $\mathrm{mgL}^{-1}$ & $0.45( \pm 5.435)$ & 0.33 & 0.82 \\
\hline Potasium $\left(\mathrm{K}^{+}\right)$ & $\mathrm{mgL}^{-1}$ & $0.28( \pm 0.071)$ & 0.19 & 0.36 \\
\hline Sulphate $\left(\mathrm{SO}_{4}^{-}\right)$ & $\mathrm{mgL}^{-1}$ & $3.94( \pm 2.380)$ & 2.31 & 9.06 \\
\hline Total Silica & $\mathrm{mgL}^{-1}$ & $1.64( \pm 0.353)$ & 1.30 & 2.37 \\
\hline Total Phosphate & $\mathrm{mgL}^{-1}$ & $0.12( \pm 0.026)$ & 0.11 & 0.16 \\
\hline Organic Nitrogen & $\mathrm{mgL}^{-1}$ & $1.08( \pm 0.715)$ & 0.37 & 2.05 \\
\hline Total Nitrogen & $\mathrm{mgL}^{-1}$ & $1.53( \pm 0.774)$ & 0.49 & 2.65 \\
\hline Aluminum (Al) & $\mathrm{mgL}^{-1}$ & $0.52( \pm 0.261)$ & 0.30 & 1.03 \\
\hline Iron (Fe) & $\mathrm{mgL}^{-1}$ & $0.30( \pm 0.339)$ & $\mathrm{ND}(<0.05)$ & 0.78 \\
\hline
\end{tabular}

The average value of $\mathrm{pH} 7$ was also reported by (Lacoul and Freedman 2005 \& Shimkhada 2006). However, the alkaline $\mathrm{pH}$ has been reported in the Gokyo lake of Sagarmatha National Park by (Gurung et al. 2011, Lacoul \& Freedman, 2005 and Tartari et al. 1998b).

The average value of conductivity was observed to be $11.7 \mu \mathrm{S} / \mathrm{cm}$. A slight increase in the conductivity value was observed for the deepest point of the lake i.e. $22 \mu \mathrm{S} / \mathrm{cm}$. Similar trend of conductivity was reported in a previous study of the Gosainkunda lake (Shimkhada, 2006). Lowest values were found in highly

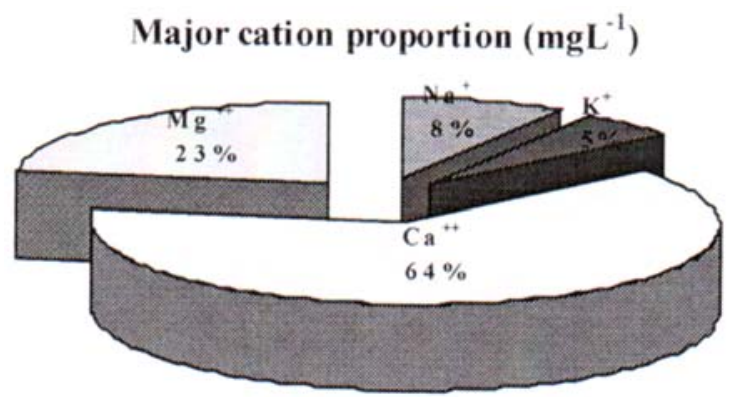

Fig. 2. Cations proportion in Gosainkunda lake transparent lakes in the Langtang region (Lacoul and Freedman, 2005). High altitude lakes generally possess low conductivity due to low weathering rates (Catalan et al., 2006). Low conductivity indicates a low total concentration of dissolved ions (Stumm and Morgan, 1996).

The concentration of major cations in lake water was noted to follow the order of $\mathrm{K}^{+}>\mathrm{Na}^{+}>\mathrm{Mg}^{++}>\mathrm{Ca}^{++}$. Calcium was found to be the dominant cation (64\%) in the lake (Figure 3). This was likely due to the presence of calcium bearing rocks and minerals in the area such as calcareous gneiss, calcite and limestone.

Major anion proportion $\left(\mathrm{mgL}^{-1)}\right.$

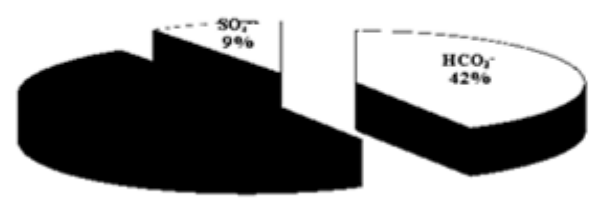

Fig. 3. Anions proportion in Gosainkunda lake 
the order of $\mathrm{SO}_{4}^{-->} \mathrm{HCO}_{3}^{->} \mathrm{Cl}^{-}$with chloride being the dominant anion (49\%) as shown in Figure 3. The concentrations of nutrients like nitrogen and phosphorus were found to be very low but in comparison, the concentration of nitrogen was considerably higher than phosphorus (Figure 4). This may be due to seepage of waste water (sewage) from the nearby lodges and hotels.

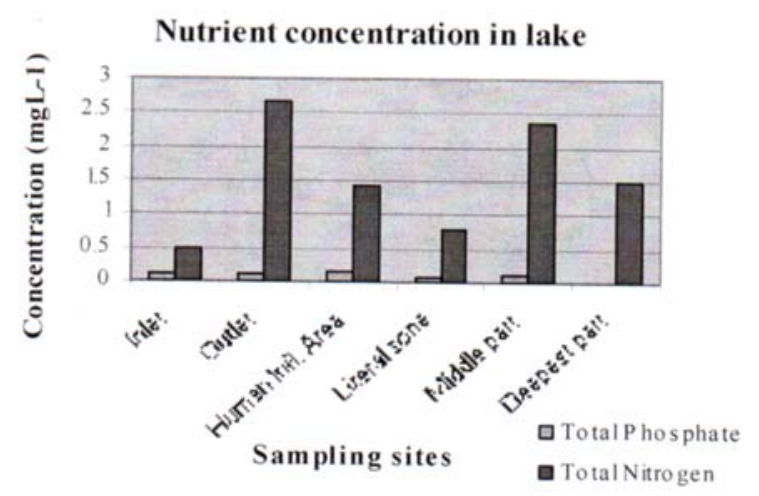

Fig. 4. Nutrient concentration in Gosainkunda lake
The Pearson correlation matrix between all the analyzed variables was determined as shown in Table 5 . The $\mathrm{pH}$ of water was highly significantly positively correlated with total dissolved solids (TDS), total suspended solids (TSS) and total hardness (TH) reflecting the influence of minerals like calcium carbonate on $\mathrm{pH}$. Likewise, the concentration of calcium ions in lake water was highly correlated positively with total hardness and chlorine concentration. Also, sodium ion concentration, sulphate ion concentration and silica were all highly positively correlated with each other. Water temperature was noted to be highly negatively correlated with sodium, sulphate and silica concentrations, suggesting lower dissolution rates as temperature increased in the range of water temperature measured. Likewise, total phosphate was highly negatively correlated with total suspended solids and aluminum concentration as was potassium concentration with organic nitrogen and total nitrogen concentrations (Table 5).

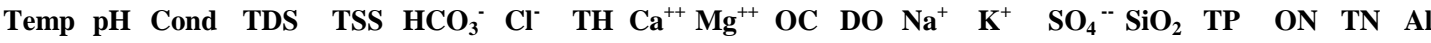

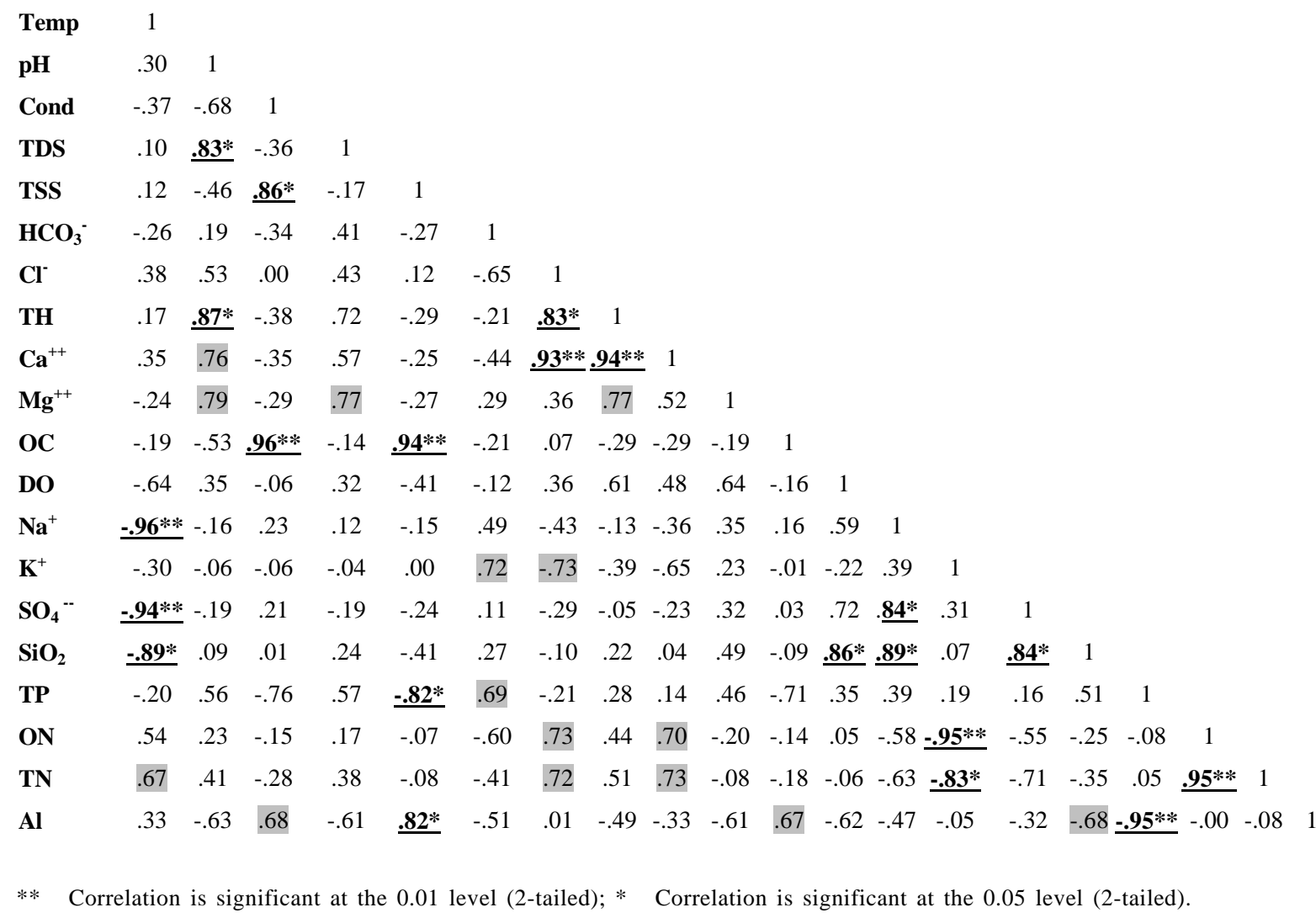


Good positive correlations (at $\mathrm{P}=0.05$ level) were observed between water $\mathrm{pH}$ and calcium, magnesium, chlorine, and total phosphate concentrations reflecting that increased amounts of these ions lead to higher water $\mathrm{pH}$ values. Also, as expected, total dissolved solids was significantly positively correlated with calcium, magnesium, total phosphate and total hardness of water as were the latter parameters also positively correlated among each other (Table 5). Less well explained were correlations between temperature and $\mathrm{ON}$ and $\mathrm{TN}, \mathrm{Al}$ and $\mathrm{OC}$, potassium and bicarbonate ion concentrations, and dissolved oxygen and magnesium, sodium and sulphate concentrations.

Low concentration of iron was detected in site GK6. Whereas the average value of $\mathrm{Al}\left(0.52 \mathrm{mgL}^{-1}\right)$ was detected in all the sampling sites of lake ranging from $0.3 \mathrm{mgL}^{-1}$ to $1.03 \mathrm{mgL}^{-1}$ at sites GK1 to GK6 respectively. With increasing acidification, aluminum (Al) concentration commonly increases in surface water (Lydersen et al., 2002). The maximum concentration of Al was observed where $\mathrm{pH}$ was low at site GK6, the deep part of the lake. High concentration of $\mathrm{Al}$ is toxic to aquatic biota (Baker \& Schafield 1982; Hutchinsion et al. 1989) and can be expected to have an adverse effect on the biodiversity of the lake.

High altitude freshwater lakes are fragile and very sensitive ecosystem. All the aquatic life depends on the stability of water chemistry; thus, any significant changes in these lentic systems can lead to imbalance and adverse impacts on the organisms dwelling therein. Being located in remote area, alpine lakes are excellent indicators of long- range and other airborne pollutants. However, most of the high altitude lakes of Nepal have their own religious values as such they are also becoming impacted by cumulative effects of various anthropogenic. The lake Gosinkunda is in oligotrophic status, measuring low nutrient contents with neutral $\mathrm{pH}$ values as well as negligible concentration of trace metals. Calcium $\left(\mathrm{Ca}^{++}\right)$and chloride $\left(\mathrm{Cl}^{-}\right)$are the major cations and anions predominant in the lake water, respectively. The presence of chloride ions indicate some anthropogenic impact, which might be due to discharge of wastewater directly into the lake from the four lodges frequented by tourists. Therefore, it is recommended that a regular monitoring is required to assess the extent and severity of anthropogenic and natural impacts and compliance through legal enforcement conservation measures be taken to conserve this higly precious high altitude lakes.

\section{Acknowledgements}

This research was initiated and supported technically as well as financially by Aquatic Ecology Centre (AEC), School of Science, Kathmandu University, Dhulikhel. Authors are thankful for assistance and cooperation to Sudip Niraula, Lekhendra Tripathi, Kolit Shakya and Saneer Lamichane during the field sampling.

\section{References}

Aizaki, M., A. Terashima, H. Nakahara, T. Nishio and Y. Ishida. 1987. Trophic status of Tilitso, a high altitude Himalayan lake. Hydrobiologia 153: 217-224.

APHA, AWWA \& WEF. 1998. Standard methods for the examination of water and wastewater. American Association of Public Health, American Water Works Association and the Water Pollution Control Federation, American Public health Association, $20^{\text {th }}$ Edition, Washington. D.C. 1268 p.

Baker, J.P. and C.L. Schafield. 1982. Aluminium toxicity to fish in acidic waters. Water Air and Soil Pollution 18: 289-309.

Bhuju, U.R., M. Khadka, P.K. Neupane and R. Adhikari. 2010. A map based inventory of lakes in Nepal. Nepal Journal of Science and Technology 11: 173-180.

Cantonati, M., G. Corradini, I. Juttner and E.J. Cox. 2001 Diatom assemblages in high mountain streams of the Alps and the Himalaya, Nova Hedwigia, Beiheft Algae and Streams Environments123: 37-61.

Catalan, J., L. Camarero, M. Feilip, S. Pla, M. Ventura, T. Buchaca, F. Bartumeus, G.DC Mendoza, A. Miro, E.O. Casamayor, J.M. Medina-Sanchez, M. Bacardit, M. Altuna, M. Bartrons and D.D.De Quijano. 2006. High mountain lakes: extreme habitats and witnesses of environmental changes. Limnetica 25 (1-2):551-584.

Drever, J. I. and J. Zobrist. 1992. Chemical weathering of silicate rocks as a function of elevation in the southern Swiss Alps. Geochin. Cosmochim. Acta 56: 3209-3216.

Galassi, S., S. Valsecchi and G. Tartari. 1997. The distribution of PCB's and chlorinated pesticides in two connected Himalayan lakes. Water, Air and Soil Pollution 99: 717-725.

Göransson, E.R.K. Jonson and A. Wilander. 2003. Representative of a mid-lake surface water chemistry sample. Environ Monit. Assess. 95: 221-238.

Gosso, E., G. Tartari, S. Valsecchi, S. Ramponi and R. Baudo. 1993. Hydrochemistry of remote high altitude lakes in the Himalayan region. Verh. int. Ver. Limnol., 25: 800-803. 
Gujja, B., A. Chatterjee, P. Chandan, N. Pradhan, B. Khan, L. Lifeng and Z. Mingxian. 2007. Conservation of high -altitude wetlands: Experiences of the WWF Network. Mountain Research and Development 27(4): 368-371.

Gurung, S., S. Sharma, I. Juttner, C.M. Sharma and R.M. Bajracharya 2011. Physico - Chemical Parameters of Gokyo lakes: High altitude Himalayan freshwater lakes, natural resources management: In Reviews and Research in the Himalayan Watersheds II, Eds. Balla, M. and Sing, Abadhesh, A special publication of NUFU HUMUNET Project, Vol. II).

Hutchinson, N.J., K.E. Holtze, J.R. Munro and T.W. Pawson. 1989. Modifying effects of life stage, ionic strength and post-exposure mortality and lethality of $\mathrm{H}^{+} \mathrm{Al}$ to lake trout and brook trout. Aquat. Toxicol., 15: 1-26.

Kafle, G. and I.T. Savillo. 2009. Present status of Ramsar sites in Nepal, International Journal of Biodiversity and Conservation 1 (5) and 146-150.

Koinig, K.A. Sommaruga -Wograth, S., Schmidt, R. Tessadri, R., Psenner, R. 1998. Acidification processes in high alpine lakes Ed. A. Balkema Publishers Rotterdam, The Netherlands. Pp. 45-54.

Lacoul, P. and B. Freedman. 2005. Physical and chemical limnology of 34 waterbodies along a tropical to alpine altitudinal gradient in Nepal. Internat. Rev. Hydrobiol. 90 (3): 254-276.

Lami, A., P. Guilizzoni., A. Marchetto, R. A Bettinetti and D. J. Smith. 1998. Palaeolimnological evidence of environmental changes in some high altitude Himalayan lakes (Nepal). Mem. Ist. Ital. Idrobiol. 57: 107-130.

Liu, C. and C.K. Sharma (eds.). 1988. Reports on first expedition to glaciers and glacier lakes in the Pumqu (Arun) and Poiqu (Bhote -Sun Koshi) river basins, Xizang (Tibet), China. Science Press, Beijing, China, $191 \mathrm{p}$.

Löffler, H. 1969. High altitude lakes in Mt Everest region. Verh. Int. Ver. Limnol. 17: 373-385.

Lydersen, E., S. Lofgren and R.T. Arnesen. 2002 Metals in Scandanavia surface waters; effects of acidification, liming and potential reacidification. Crit. Rev. Environ. Sci. Technol. 32: 73-295.

Manca, M. and G. Mura. 1997. On Branchinecta orientalis Sars (Anostraca) in the Himalayas. Hydrobiologia 356: 111-116.

Manca, M., P. Cammarano and T. Spagnuolo. 1994. Notes on Cladocera and Copepoda from high altitude lakes in the Mount Everest Region (Nepal). Hydrobiologia 287: 225-231.

Mosello, R., B.M. Wathne, L. Lien and H.J.B. Birks. 1995. $\mathrm{Al}: \mathrm{PE}$ projects, Water chemistry and critical loads. Water, Air and Soil Pollution 85: 493-498.

Niraula, S.R. 2011. Application of GIS in Bathymetric mapping of Gosainkunda lake. M.Sc. Dissertation. Department of Environmental Science and Engineering, Kathmandu University, Dhulikhel, Kavre.

Okino, T. and Y. Satosh. 1986 Morphology, physics, chemistry and biology of lake Rara in West Nepal. Hydrobiologia 140: 125-133.

Psenner, R. 1989. Chemistry of high mountain lakes in siliceous catchments of the central eastern Alps. Aquat. Sci. 51:108-128.

Shimkhada, B. 2006. Diatoms as a indicator of environmental change in lakes and ponds of lowlands middle hills and high Himalaya of Nepal. Ph. D. Thesis, Faculty of Biology, University of Bielefeld, Bielefeld, Germany.

Smol, J.P., I.R. Walker and P.R. Leavitt. 1991. Paleolimnology and hindcasting climatic trends. Verh. Internat. Verein. Limnol. 24: 1240-1246.

Strang, D., J. Aherene and P. Shaw. 2010. The hydrochemistry of high- elevation lakes in the Georgia Basin, British Columbia. J. Limnol 69(Suppl. 1):5666.

Stumm, W. J.J. Morgan. 1996. Aquatic chemistry chemical equilibria and rates in natural water. Wiley International publication, New York.

Tartari, G., G.A. Tartari, S. Valsecchi and M. Camusso. 1997 Cadastre and hydrochemistry of high altitude lakes in the Mount Everest region. Verh. Int. Ver. Limnol. 26: 397-402.

Tartari, G.A., G. Tartari and R. Mosello. 1998a. Water chemistry of high altitude lakes in the Khumbu and Imja Kola valleys (Nepalese Himalayas). In: Limnology of high altitude lakes in the Mt. Everest Region, Nepal. Eds A. Lami and G Giussani, Mem. Ist. Ital. Idrobiol. 57: 51-76.

Tartari, G.A., P. Panzani, L. Adreani, A. Ferrero and C. De Vito. 1998 b. Lake cadastre of Khumbu Himal region: Geographical - geological - limnological data base. In: Limnology of high altitude lakes in the Mt Everest Region (Nepal). Mem. Ist. ital. Idrobiol. (Eds A. Lami \& G. Giussani) 57: 151-235. 